\title{
Relationship Between Anxiety Levels With Hypertension Events In Elderly In Public Healt Ujung Loe
}

\author{
Nirmawati 1, Adam², Andi Suswani ${ }^{3}$ \\ S1 Nursing Study Program, Stikes Panrita Husada Bulukumba, Indonesia1 \\ Departemen Community and Family Nursing, Stikes Panrita Husada Bulukumba, Indonesia ${ }^{2}$ \\ Departemen Maternal and Child Healt Nursing, Stikes Panrita Husada Bulukumba ,Indonesia ${ }^{3}$
}

\author{
Corresponding Autor : Aderialmakmur@yahoo.com
}

\begin{abstract}
Hypertension is an increase in blood pressure $>140 / 90 \mathrm{mmHg}$. with increasing age, almost all people experience hypertension. Cases of hypertension that occur at the health center at the end of the street are 78 people who suffer and among them 52 elderly people who suffer from hypertension. The purpose of this study was to determine the relationship between the level of anxiety with the incidence of hypertension in the elderly at Puskesmas Ujung Loe in 2018. Research methods: This study used an analytic observational design with a "cross-sectional" approach. From the results of preliminary studies conducted by researchers on July 2, 2018, with 34 respondents. The measuring instrument used is an observation sheet. Data analysis was used using Fisher's test, a purposive sampling technique. The results of research conducted using the fisher test obtained $\mathrm{p}$-value $=0.034(\mathrm{p} \leq(\alpha=0,05)$, then Ho was rejected and Ha was accepted. So it can be concluded that "There is a relationship between" 'Relationship between Anxiety Levels and Hypertension in the Elderly at Ujung Loe Public Health Center in 2018. It is recommended for families to be able to provide care for the elderly especially to help reduce the risk factors for hypertension in the elderly.
\end{abstract}

\section{Keywords: Anxiety, Hypertension, Elderly}

\section{INTRODUCTION}

Aging (getting old) is a process of slowly disappearing the ability of the network to repair itself or replace and maintain its normal function so that it cannot survive the infection and repair the damage suffered. (Annisa \& Ifdil, 2016).

According to the World Health Organization WHO (2015), it is explained that a person is said to have hypertension when systolic pressure $>140 \mathrm{mmHg}$ while diastolic pressure $>90 \mathrm{mmHg}$, with increasing age, almost everyone experiences an increase in WHO blood pressure, (2018) classifies the elderly into 4 namely, middle-age (middle age) 45-59 years, elderly (elderly) 60-74 years, old age (old) 75-90 years and very old age (very old) above 90 years. Indonesia is one of the countries entering the era of the aging structured population (aging structured population). Demographically, the 
elderly in Indonesia are 20,547,541 people. If we look at the distribution of the elderly population according to provinces in Indonesia, the percentage of the elderly population is above $10 \%$ while the highest is in the DI Yogyakarta Province (13.04\%), East Java (10.40\%), Central Java (10.34\%), Bali (9.78\%), North Sulawesi (8.45\%), and South Sulawesi (8.34\%)(Pusat Data Dan Informasi Kementrian Kesehatan RI, 2013).

Based on data obtained from the Ministry of Health Data and Information Center in 2013, South Sulawesi Province ranks fifth as the province with the highest number or percentage of elderly people in Indonesia, amounting to $8.34 \%$. Of these, $3 \%$ of them suffer from a disease such as degenerative diseases, systemic diseases, infectious diseases, chronic diseases, and psychosocial disorders. A psychosocial disorder that is often experienced by the elderly is depression. The number of depressed patients in the elderly in 2012-2013 in South Sulawesi Province reached 1.23\% from $8.34 \%$ of the elderly population (Kementrian Kesehatan RI, 2013).

Based on data from (Dinas Kesehatan Provinsi Sulsel, 2015) from 24 districts or cities with 440 health centers in South Sulawesi, the prevalence of hypertension obtained through blood pressure measurements at age $>18$ years was $28.1 \%$. And those obtained through questionnaires diagnosed by health workers were $10.3 \%$, those diagnosed by health workers were taking medicine as much as $10.5 \%$, and there were $0.2 \%$ taking the medication themselves. Regency. The second highest Bulukumba after Kab. Enrekang with the number of cases of hypertension as much as $30.8 \%$.

Bulukumba district disease prevention and control agency said that the number of cases of hypertension in the district. Bulukumba increased from year to year namely in 2014 as many as 6,355 people and in 2016 as many as 10,430 people. Among the 20 public health in Kab. Bulukumba, Puskesmas Ujung Loe found that there were 891 cases of hypertension (Dinkes Kab.Bulukumba, 2016 ). The results of previous studies conducted by Uswandari, (2017) analysis used product moment of a person by using the correlation test results showed that there was a significant positive relationship between anxiety and the incidence of hypertension in the elderly $p=0.020$. This is in line with research conducted by Puspa, (2014) from the results of statistical tests showing there is a significant relationship between anxiety and hypertension $\mathrm{p}<0.05$.

Based on the results of the initial survey found the number of cases of hypertension that occurred in Ujung Loe Health Center 78 people suffered and of the 52 elderly people who suffer from hypertension. Some elderly people have experienced anxiety for 
years due to suffering from hypertension. Based on data obtained at the public health center at the end of the sub-district health center, at the end of the working area consisting of several villages. Padalloang Village, Seppang Village, Bijawang Village, Salemba Village, Bulu Longrong Village, and Garanta Village, have several health service facilities which are spread in the village or village, such as pustu, polindes (poskesdes), and posyandu. Data from several diseases from the Public Health, one of which is hypertension and elderly data in the working area of the end of the health center 52 people consisting of data from each village / has been identified by people who have hypertension for the elderly. Padalloang Village as many as 8 elderly, Seppang Village as many as 9 elderly, Bijawang village as many as 5 elderly, Salemba village as many as 11 elderly, Bulu Longrong Village as many as 6 elderly, Garanta Village as many as 13 elderly initially suffered from hypertension. The purpose of this study was to determine whether there is a relationship between anxiety levels and the incidence of hypertension in the elderly at Ujung Loe Health Center in 2018.

\section{MATERIAL AND METHODS}

The design of this study is analytical research with a "cross-sectional" approach where data concerning independent variables and dependent variables are collected at the same time (Notoadmodjo, 2012). Which aims to determine the relationship of anxiety levels with the incidence of hypertension in the elderly at Ujung Loe Puskesmas. Population is the whole object of research or the object under study (Notoatmodjo S. , Metodologi Penelitian Kesehatan, 2012). The population in this study based on data obtained from the public health was 52 people.

Sampling in this study was conducted using non-probability sampling that is sampling not random or non-random. By using a purposive sampling technique, it is based on certain considerations made by the researchers themselves, based on the characteristics or characteristics of the population that have been known previously (Notoatmodjo, 2012). The sample is part of the whole object studied and is considered to represent the entire population (Setiadi, 2013). The sample in this study amounted to 34 people.

The research instrument for the anxiety variable is an observation sheet to determine the level of anxiety in the elderly. Meanwhile, the instruments used for hypertension variables are blood pressure meters and stethoscopes. 
Data were analyzed based on measuring scale and research objectives using computerized program software. Data were analyzed by (1) Univariate Analysis is an analysis conducted to analyze each variable Sujarweni, (2014). Univariate analysis for the independent variable is anxiety while the dependent variable is hypertension (2) Bivariate analysis in this study is to analyze the relationship between obesity and hypertension. The statistical test used was the chi-square test if it met the requirements but if it did not meet the requirements the Kolmogorov Smirnov test was used. This test aims to see whether or not there is a significant correlation between the observed frequency distribution and the expected significance level of 0.05 . If P-Value $<0.05$ means there is a significant relationship (Ho is rejected) while P-Value $>0.05$ means there is no significant difference (Ho is accepted).

RESULT

Table 1. Frequency Distribution Based on Characteristics of respondents

\begin{tabular}{lcc}
\hline \multicolumn{1}{c}{ Characteristics } & n & Percentage (\%) \\
\hline Gender & 16 & 47.1 \\
Male & 18 & 52.9 \\
Female & & \\
Age & 11 & 32.4 \\
45-59 Year & 11 & 32.4 \\
60-70 Year & 12 & 35.2 \\
>70 Year & 11 & 32.4 \\
45-59 Year & & \\
Level Of Education & 22 & 64.7 \\
Promary School & 9 & 26.5 \\
Middle School & & \\
Job & 14 & 41.2 \\
IRT & 11 & 32.4 \\
Farmers & 3 & 8.8 \\
entrepreneur & 5 & 14.7 \\
Retired & 1 & 2.9 \\
Teacher & 34 & 100,0 \\
\hline Amount & & \\
\hline
\end{tabular}

Based on (table 1) the distribution of elderly by sex it can be seen that out of 34 elderly, 18 elderly with female sex (52.9\%) and as many as 16 elderly with male sex around (47.1\%), the distribution of elderly based on age can it is known that out of 34 elderly, 12 are aged $>70$ years (35.2\%). 11 elderly with age 45-59 years (32.4\%). the distribution of the elderly based on their level of education can be seen that out of 34 elderly people, as many as 22 elderly with basic education or around (64.7\%) and as many as 3 elderly with higher education (8.8\%). the distribution of the elderly based on the type of work can be seen that out of 34 elderly people, 14 of them are IRT $(41.2 \%)$ and 1 elderly person works as a civil servant (2.9\%). 
Table 2. Frequency distribution of the number of respondents based on anxiety level, with the incidence of hypertension

\begin{tabular}{lccc}
\hline & Varible & n & Percentage (\%) \\
\hline Level Of Anxiety & & & \\
Light & 19 & 55,9 \\
Is & 8 & 23,5 \\
Weight & 7 & 20,6 \\
Hypertension & & \\
High & 20 & 58,82 \\
Lower & Amount & 14 & 41,17 \\
\hline & 34 & 100 \\
\hline
\end{tabular}

Based on (table 2) Distribution of the Number of Respondents Based on the anxiety level of the Elderly, it can be seen that from 34 the number of Elderly, as many as 19 elderly with mild category anxiety level (55.9\%), moderate as much as 8 elderly (23.5\%) and mild as much as 7 elderly with anxiety levels weight category (20.6\%).Distribution of Number of Respondents Based on Elderly Hypertension Degrees, it can be seen that from 34 total Elderly, as many as 20 elderly with mild category of hypertension (58.82\%), as many as 14 elderly with severe category of hypertension (41.17\%).

Table 3. Relationship between Anxiety Level and Occurrence of Hypertension

\begin{tabular}{|c|c|c|c|c|c|c|}
\hline \multirow{3}{*}{ Anxiety level } & \multicolumn{4}{|c|}{ The incidence of hypertension } & \multirow{3}{*}{ Amount } & \multirow{3}{*}{$P$ Value } \\
\hline & \multicolumn{2}{|c|}{ Weight } & \multicolumn{2}{|c|}{ Light } & & \\
\hline & $\mathrm{n}$ & $\%$ & $\mathbf{n}$ & $\%$ & & \\
\hline Light & 14 & 41,17 & 5 & 14,70 & 19 & 0,034 \\
\hline Is & 4 & 11,76 & 4 & 11,76 & 8 & \\
\hline Weight & 2 & 5,8 & 5 & 14,70 & 7 & \\
\hline
\end{tabular}

Based on (table 3) from the fisher test results obtained Expected Count values below 5 are 4 cells (66.7\%). Where can be known that of 34 elderly. A total of 14 elderly (63.6\%) with mild anxiety experienced mild hypertension, and 5 elderly (41.6\%) with mild anxiety experienced severe hypertension, then 4 elderly (18.2\%) with moderate level of anxiety who experienced hypertension in mild degree category, and as many as 4 elderly (33.3\%) with moderate level of anxiety who experienced severe category hypertension and 4 elderly (18.2\%) with severe anxiety level who experienced mild category of hypertension, and as many as 3 elderly (25\%) with severe anxiety who experience hypertension in the severe degree category. 
From the fisher test results with the level of confidence $(\alpha=0.05), \mathrm{p}$ values $<\alpha$ $(0.034<0.05)$ were obtained, then Ha was accepted and Ho was rejected. So it can be concluded that, "There is a Relationship Between Anxiety Levels and Incidence of Hypertension in the Elderly in Ujung Loe Health Center.

\section{DISCUSSION}

Distribution of Number of Respondents Based on the Anxiety Level of the Elderly, it can be seen that from 34 the number of Elderly, as many as 19 elderly with mild anxiety level (55.9\%), as many as 8 elderly with moderate anxiety level (23.5\%), and as many as 7 elderly with anxiety levels weight category (20.6\%).

According to Budi Setyawan, (2017). The Relationship Between Stress and Anxiety Levels with the Occurrence of Hypertension in the Elderly at Samarinda Islamic Center Clinic, it is known that almost half of respondents who have mild anxiety are 32 people (39\%), after that, a small proportion of respondents with moderate anxiety are 21 people (25.6\%) and almost half of the respondents with severe anxiety were 29 people (35.4\%).

The results of the study were supported by Potter and Perry (2009) in Budi Setyawan, (2017). states that anxiety often increases pressure which can also cause feelings of anxiety. This is in line with the results of Wadhwa et.al's research (2007) which revealed depression and anxiety have a relationship with the incidence of hypertension in a person. This factor is due to autonomic nerves that respond to unclear non-specific threats that are often found and are often a normal emotion (Budi Setyawan, (2017).

Anxiety is an everyday experience faced by individuals. Anxiety becomes a problem when individuals become unable to control it so that it has an impact on socially and economically decreasing productivity. Anxiety is a feeling of anxiety, worry, or discomfort as if something is happening as a threat. Anxiety is different from fear. Fear is an intellectual assessment of something dangerous, whereas Anxiety is an emotional response to that assessment (Keliat, Wiyono, \& Susanti, 2013).

About the anxiety level of elderly respondents more common in women of course influenced by various factors, one of which is gender. Women more easily feel anxious, this is because women have broader and closer social relations with the environment. This is due to many elderly people thinking about their health problems and can not be as active as before. Unhealthy lifestyles make some elderly people experience hypertension, because of the habit of frequently consuming foods that are salty and 
contain fat which triggers an increase in blood pressure. The purpose of this study was to determine the relationship of anxiety levels with the incidence of hypertension in the elderly at Ujung Loe Health Center.

\section{CONCLUSION}

Based on the specific objectives revealed in the previous chapter, the researchers formulated the conclusion that the level of anxiety of the elderly in the Ujungloe puskesmas was at a mild anxiety level, the degree of elderly hypertension at the Ujungloe Puskesmas was at a mild degree of hypertension, there was a relationship between the level of anxiety and the incidence of hypertension in the elderly at the Ujung Puskesmas. Loe 2018, based on the benefits stated in the previous chapter, the advice that can be given by researchers is that families are expected to be able to provide care to their families, with the results of this study it is expected that the elderly can reduce the risk factors that can aggravate complaints and so that this research can be reference material for further research.

\section{REFERENCES}

Annisa, D. F., \& Ifdil. (2016). Konsep Kecemasan (Anxiety) Pada Lanjut Usia (Lansia). Konselor Volume 5.

Budi Setyawan, (2017). Hubungan Antara Tingkat Stres Dan Kecemasan Dengan Kejadian Hipertensi Pada Lansia Di Klinik Islamic Center Samarinda

Baredero, M., Dayrit, M. W., \& Maratning, A. (2016). Kesehatan Mentak Psikiatri. Jakarta: Buku Kedokteran Egc.

Darma, K. K. (2017). Metodologi Penelitian Keperawatan. Jakarta: Tim.

Dian uswandari. (2017). hubungan antara kecemasan dengan kejadian hipertensi pada lansia di panti sosial tresna werdha.

Dinas Kesehatan Provinsi Sulsel. (2015). Profil Kesehatan Provinsi Sul Sel. Sulawesi Selatan: Dinas Kesehatan Provinsi Sulawesi Selatan.

Handayono, L. (2018). Asuhan Keperawatan Pada Lansi.

Hawari, D. (2011). Manajemen Stres Cemas Dan Depresi. Jakarta.

Hidayati, N. (2016). Mengatasi Kecemesan Siswa Untuk Meningkatkan Motivasi Belajar Dalam Pembelajaran Matematika.

Keliat, B. A., Wiyono, A. P., \& Susanti, H. (2013). Manajemen Kasus Gangguan Jiwa. Jakarta: Buku Kedokteran Egc. 
Laka, O. K., Widodo, D., \& Rahayu, W. (2018). Hub Ungan Hipertensi Dengan Tingkat Kecemasan Pada Lansia Di Posyandu Desa Banjarejo Kecematan Ngantang Malang. Nursing News.

Muhadi. (2016). Jnc 8: Evudence-Based Guideline Penanganan Pasien Hipertensi Dewasa. Cdk-236/Vol. 43 No.1.

Muhammad, A. (2009). Memahami Bahaya Serangan Jantung. Jogjakarta: Power Books (Ihdina).

Notoadmodjo, S. (2012). Metodologi Penelitian Kesehatan. Jakarta: PT Rineka Cipta.

Noviyanti. (2015). Hipertensi Kenali, Cegah, Dan Obatai. Yogyakarta: Notebook.

Nurarif, A. H., \& Kusuma, H. (2015). Aplikasi Asuhan Keperawatan Berdasarkan Diagnosa Medis Dan Nanda Nic-Noc, Jilid 2. Jogjakarta: Mediaction.

Pangastuti, M. (2014). Pengaruh Pelatihan Berfikir Positif Terhadap Penurunan Tingkat Kecemasan Pada Siswa Sma. Maya Pangastuti, Pengaruh Berfikir Positif, 43.

Prabaningrum , N., Kusumawati, Y., \& Nugr, F. S. (2014). Hubungan Antara Perilaku Pengendalian Hipertensi Dengan Keberhasilan Penurunan Tekanan Darah Pada Kejadian Hipertensi Esensial Di Puskesmas Kraton Surakarta.

Pranama, K. D., Okatiranti, \& Ningrum, T. P. (2016). Hubungan Tingkat Kecemasan Dengan Kejadian Hipertensi Di Pnti Sosial Tresna Werdha Senjarawi Bandung . Jurnal IImu Keperawatan Vol. IV.

Prihatanti, N. R. (2010). Hubungan Antara Kecemasan.

Pusat Data Dan Informasi Kementrian Kesehatan Ri, 2013. (N.D.). Skripsi Hubungan Dukungan Keluarga Dengan Kejadian Depresi Pada Lansia.

Puspa, D. (2014). Hubungan Kecemasan Dengan Kejadian Hipertensi Pada Lansia Di Wilayah Kerja Puskesmas Poris Plawad Kota Tangerang.

Puspitasari, Y. P., Abidin, Z., \& Sawitri, D. R. (2010). Hubungan Antara Dukungan Sosial Teman Sebaya Dengan Kecemasan Menjelang Ujian Nasional Pada Siswa Xii Reguler Sman 1 Surakarta. Jurnal Psikologi, 2.

Setiadi. (2013). Konsep Dan Praktik Penulisan Riset Keperawatan Edisi 2. Yogyakarta: Grahaya Ilmu.

Setyawan, A. B. (2017). Hubungan Antara Tingkat Stres Dan Kecemasan Dengan Kejadian Hipertensi Pada Lansia Di Klinik Islamic Center Samarinda . Jurnal IImu Kesehatan. 
Sujarweni, V. W. (2014). Metodologi Penelitian Keperawatan. Cetakan I. Yogyakarta: Gava Media.

Sutanto . (2010). Cekal (Cegah Dan Tangkap) Penyakit Modern . Yogyakarta: Cv Andi Offset.

Suyanto. (2011). Metodologi Dan Aplikasi Penelitian Keperawatan. Yogyakarta: Nuha Medika.

Tanto, C., Liwang, F., Hanifati, S., \& Pradipta, E. A. (2014). Kapita Selekta Kedokteran Edisi IV Jilid Ii. Jakarta: Media Aesculapius.

Udjianti, W. J. (2013). Keperawatan Kardiovaskuler. Jakarta Selatan: Salemba Medika.

Uswandari, B. D. (2017). Hubungan Antara Kecemasan Dengan Kejadian Hipertensi Pada Lansia Di Panti Sosial Tresna Werdha.

Walasary, S. A., Dundu, A. E., \& Kaunang, T. (2015). Tingkat Kecemasan Pada Siswa Kelas Xii Sman 5 Ambon Dalam Menghadapi Ujian Nasional. Jurnal Clinik, 511.

WHO. (2018). Klasifikasi Usia Lanjut. di Akses 1 juni 2018 : hhtp://Wordpres 